„Bohemistyka” 2021, nr 1, ISSN 1642-9893

Pavel SOJKA

DOI: $10.14746 /$ bo.2021.1.2

Univerzita Karlova

\section{Prézentní časování sloves vzorů kryje a kupuje ve spisovné češtině: variantnost, nebo unifikace?}

Keywords: Czech, historical grammar, conjugation

Klíčová slova: český jazyk, historická mluvnice, časování

\section{Abstract}

The morphological variation in the present-tense conjugation of the kryje and kupuje conjugation types ( $3^{\text {rd }}$ verb class) as a result of gradual vowel shifts has been in progress since the $15^{\text {th }}$ century. The gradual back shift towards the endings $-u$ and $-o u$ used to be explained as a result of paradigm levelling within the conjugation types of the $1^{\text {st }}, 2^{\text {nd }}$ and $3^{\text {rd }}$ verb class. In 1993, these endings were codified alongside with the endings $-i$ and $-i$. However, this codification act hasn't met with general approval, because the incidence of the endings $-u$ and $-o u$ in standard language is not equal: while the ending $-u$ has been standardizing, the ending $-o u$ has still retained its markedness or can be even regarded as colloquial, in particular in written standard language. In this paper, we aim to answer the question how the endings $-u$ and -ou are applied in present-day TV journalism, namely in the Interview ČT24 show.

Tvarová konkurence v prézentním časování sloves vzorů kryje a kupuje jako

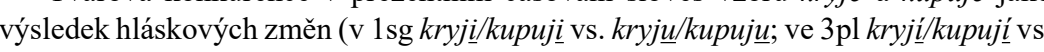
kryjou/kupujou) existuje v češtině již od 15. století. Progrese koncovek -u a -ou se tradičně vysvětlovala jako projev tvarového vyrovnávání uvnitř 1.-3. slovesné třídy. V roce 1993 byly proto u vzorů kryje a kupuje koncovky $-u$ a -ou přijaty do kodifikace spisovného jazyka. Toto rozhodnutí se však nesetkalo s všeobecným souhlasem, nebot' pozice obou koncovek ve spisovných textech není stejná: zatímco koncovka -u se postupně neutralizuje, koncovka -ou si stále zachovává značný stupeň příznakovosti, či dokonce nespisovnosti (zejména v psaných textech). V tomto př́spěvku si klademe otázku, jak se tato tvarová konkurence projevuje $\mathrm{v}$ dnešní televizní publicistice, konkrétně v diskusním pořadu Interview ČT24.

\section{1. Úvod}

V současném spisovném českém časování existuje několik důležitých př́ípadů tvaroslovné variantnosti, přičemž v některých případech se tato variantnost projevuje i v kodifikaci: patří sem naprríklad přechod některých sloves vzorů bere a maže ke vzoru dèlá (typ češu/česám-češ/česej), pronikání variant podle vzoru mine do příčestí činného rodu mužského sloves vzorů tiskne a začne (typ bodl/bodnul - zajal/zajmul) či konkurence typu oni sázejí - oni sází.

Pozoruhodným př́kladem tvaroslovné variantnosti jsou však bezesporu i dublety v indikativu prézentu aktiva sloves 3 . prézentní třídy, tedy sloves vzorů kryje a kupuje. Variantnost se zde projevuje jednak v 1 . osobě singuláru (dále jen $1 \mathrm{sg}$ ), jednak ve 3 . osobě plurálu (dále jen $3 \mathrm{pl}$ ). V 1sg lze v souladu s kodifikací použít u obou vzorů nejen původně kodifikovanou koncovku $-i$, nýbrž i nověji kodifikovanou koncovku $-u$. Ve $3 \mathrm{pl} \mathrm{je} \mathrm{situace} \mathrm{analogická:} \mathrm{vedle} \mathrm{dříve} \mathrm{kodifikované}$ koncovky -í připouští novější kodifikace také koncovku -ou. Cesta $\mathrm{k}$ těmto kodifikovaným dubletám byla poměrně komplikovaná a především kodifikace koncovky -ou vyvolala a dosud vyvolává protichůdné reakce.

V tomto příspěvku pojednáváme o tvaroslovné variantnosti ve 3. prézentní tř́dě z pohledu teoretického i empirického. Především hodláme osvětlit, jak se dnes tato variantnost projevuje $\mathrm{v}$ jednom konkrétním typu mluvených spisovných projevů. Nejprve však zasadíme problém do kontextu tvaroslovného vývoje slovanských jazyků, samozřejmě s dưrazem na vývoj v češtině.

\section{Historický vývoj tvarů 1sg a 3pl}

Zakončení tvarů 1 sg a 3 pl se vlivem hláskových změn vyvíjelo. Ve staroslověnštině, odrážející stav v pozdní praslovanštině, existovalo $\mathrm{v} 1$ sg tematických sloves jednotné zakončení $-\boldsymbol{x}$ a u sloves atematických zakončení $-M b$. Ve 3 pl pak měla slovesa tematická i atematická zakončení -mb (s předcházejícím s, nebo a; viz Večerka 2006, s. 174n.). Další hláskový vývoj vedl v jednotlivých slovanských 
jazycích k odlišným výsledkům, a to jak ve tvaru $1 \mathrm{sg}$, tak i ve tvaru 3pl. Dnešní situaci ve spisovných útvarech slovanských jazyků s omezením na slovesa pravidelná - přibližuje Tabulka 1.

Tabulka 1. Zakončení tvarů 1 sg a $3 \mathrm{pl}$ pravidelných sloves

\begin{tabular}{|c|c|c|c|c|c|c|}
\hline \multirow{2}{*}{ Skupina jazykú } & \multirow{2}{*}{ Jazyk } & \multicolumn{5}{|c|}{ Zakončení } \\
\hline & & \multicolumn{3}{|c|}{$1 \mathrm{sg}$} & \multicolumn{2}{|c|}{$3 \mathrm{pl}$} \\
\hline \multirow{4}{*}{$\begin{array}{c}\text { Západoslovan- } \\
\text { ské } \\
\text { jazyky }\end{array}$} & Čeština & $-\mathrm{u}$ & $-\mathrm{i}$ & $-\mathrm{m}$ & -ou & -1 \\
\hline & Polština & -ę & & $-m$ & $-a ̨$ & \\
\hline & Slovenština & & & $-\mathrm{m}$ & -ú & -ia \\
\hline & Lužická srbština & $-\mathrm{u}$ & & $-\mathrm{m}$ & $-\mathrm{u}$ & $-\mathrm{a}$ \\
\hline \multirow{3}{*}{$\begin{array}{c}\begin{array}{c}\text { Východoslovan- } \\
\text { ské }\end{array} \\
\text { jazyky }\end{array}$} & Ruština & $-\mathrm{y}$ & & & $-\mathrm{T}$ & \\
\hline & Běloruština & $-\mathrm{y}$ & & & -ць & \\
\hline & Ukrajinština & $-\mathrm{y}$ & & & -ть & \\
\hline \multirow{4}{*}{$\begin{array}{c}\text { Jihoslovanské } \\
\text { jazyky }\end{array}$} & Slovinština & & & $-\mathrm{m}$ & -0 & $-e$ \\
\hline & $\begin{array}{l}\text { Chorvatština/ } \\
\text {-Srbština }\end{array}$ & & & $-\mathrm{m}$ & $-\mathrm{u}$ & $-\mathrm{e}$ \\
\hline & Bulharština & $-\mathrm{a}$ & & $-\mathrm{M}$ & $-\mathrm{T}$ & \\
\hline & Makedonština & & & $-\mathrm{M}$ & $-\mathrm{T}$ & \\
\hline
\end{tabular}

Z tabulky vyplývá, že z hlediska zakončení ${ }^{1}$ tvaru 1 sg existují $\mathrm{v}$ dnešních slovanských jazycích tři možnosti:

1. pouze samohláskové zakončení (východoslovanské jazyky²),

2. pouze souhláskové zakončení - $m$ (slovenština, slovinština, chorvatština, srbština, makedonština),

3. obě možnosti, a to $\mathrm{v}$ závislosti na konjugačním typu (čeština, polština, horní i dolní lužická srbština, bulharština).

${ }^{1}$ Pod pojmem zakončení zde rozumíme invariantní finální část tohoto zakončení: to je důležité u samohláskových zakončení, v nichž mohou samohlásce předcházet různé souhlásky. Pro nás je však podstatný pouze onen samohláskový invariant, nikoli souhláska před ním.

${ }^{2}$ Předchází-li samohláskové finále souhláska $j$, zapisuje se tato kombinace jako
Při pohledu na tabulku je však zároveň zřejmé, že čeština sice obecně patří do třetí skupiny, př́ísně vzato však tvoří samostatný typ, nebot' samohlásková zakončení (koncovky) zde existují dvě: $-u$ a $-i$ (o příčinách viz dále). Koncovky $-u$ a $-i$ spolu zároveň systémově souvisejí: s výjimkou nepravidelného slovesa chtít, u něhož je ve spisovné češtině pouze koncovka $-i$, obecně platí, že lze-li u konjugačního typu použít koncovku $1 \mathrm{sg}-i$, lze u něj použít i koncovku $1 \mathrm{sg}$ $-u$. Opačně to však neplatí: u některých konjugačních typů lze $\mathrm{v} 1 \mathrm{sg}$ použít pouze koncovku $-u$. Tato okolnost se v dalším průběhu výkladu ukáže jako velmi podstatná

Ve tvaru 3 pl je situace poněkud odlišná. Obecně zde můžeme vydělit dvě skupiny:

1. jazyky s jedinou koncovkou (východoslovanské jazyky, bulharština, makedonština, polština),

2. jazyky se dvěma koncovkami, a to v závislosti na konjugačním typu (čeština, slovenština ${ }^{3}$, horní i dolní lužická srbština, slovinština, chorvatština a srbština).

V jazycích se dvěma možnými koncovkami se pak ještě vydělují dvě podskupiny:

a) jazyky, v nichž ve 3 pl neexistuje dubleta,

b) jazyky, v nichž ve 3pl některých konjugačních typů dubleta existuje.

Do této druhé podskupiny patří vedle horní a dolní lužické srbštiny ${ }^{4}$ a slovinštiny ${ }^{5}$ také čeština, kde se tato tvarová synonymie týká především vzorů kryje a kupuje (a kromě toho i některých sloves vzoru maže).

\footnotetext{
${ }^{3}$ Ve slovenštině existuje pravidlo o rytmickém krácení samohlásek. Proto má

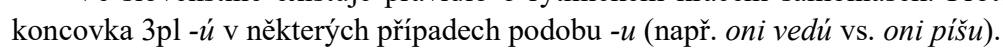

${ }^{4}$ Viz Bígl 2019, s. 20. Tvarová synonymie se vyskytuje především v dolní lužické srbštině, a to u několika konjugačních typů, např. 3pl daju/daźe, powěźe/powěźeju.

5 "Glagoli, ki se v 3. os. množine končujejo na -ijo, namesto tega končaja rabijo tudi -é: sedijo - sedé" (Toporišič 2000, s. 369; viz též De Bray 1969, s. 416).
} 
Celkově tedy můžeme konstatovat, že z hlediska variantnosti ve tvarech 1sg a 3 pl představuje čeština v kontextu slovanských jazyků anomálii, nebot' variantnost se zde týká obou dotyčných tvarů. Dubleta $-u /-i \mathrm{v} 1 \mathrm{sg}$ a dubleta $-o u /-i$ ve 3 pl jsou totiž v češtině systémově propojeny: možnost (byt' třeba $\mathrm{v}$ řečové praxi nevyužívaná) použít v $1 \mathrm{sg}$ koncovku -i nabízí možnost použít ve 3 pl koncovku -í. Jak se tento zajímavý jev v češtině vyvinul, vysvětlíme v následující části.

\section{Vývoj tvarů 1sg a 3pl v češtině}

Tematická slovesa měla původně v 1 sg jednotné zakončení $-u$, jež vzniklo z původního praslovanského - $a$ (atematická slovesa měla zakončení $-m$ ). V průběhu 14. století proběhla u sloves s měkkou souhláskou v konci základu přehláska $u>i$, takže již koncem 14 . století se v psaných textech běžně objevují varianty typu teši, proši, kupuji. Posléze se však vývoj obrací zpět k původnímu zakončení $-u$, a to působením variant typu $n e s u$, u nichž přehláska neproběhla. Od 17 . století se původní - $u$ šiří do té míry, že „, jazyku nynějším $-i$ již jen $\mathrm{v}$ řeč knižné se drží; a i sem vniká novotné - $u$ víc a více..." (Gebauer 1898, s. 7).

Ve 3pl vznikají z původního jednotného -ú vlivem přehlásky dvě různá zakončení: po tvrdých souhláskách -ou, po měkkých souhláskách $-i$. Posléze se toto $-i$ vlivem variant typu nesou mění v -ou, ale pouze tam, kde se koncové -í neodsouvalo (to se týkalo i vzorů kryje a kupuje). ${ }^{6}$ Od 17. století se tento vývoj zintenzivňuje, takže „koncovka -ínyní již jen v řeči knižné se drží; a i sem vniká novotné -ou poněkud" (Gebauer 1898, s. 25).

Pro situaci v tvarech $1 \mathrm{sg}$ a $3 \mathrm{pl}$ sloves 3 . prézentní trí́dy vyplývají $z$ uvedených Gebauerových výroků dva důležité závěry: 1 . mezi členy obou dubletních párủ existuje stylový rozdíl: koncovky $-i$ a $-i$ jsou sty-

\footnotetext{
${ }^{6}$ Např. místo 3pl kupuji nemohlo být pouhé kupuj, ke změně v -ou zde tudíž došlo, čímž vznikla podoba kupujou. Naopak místo dělají, uměji apod. mohlo být dělaj a uměj, proto zde zakončení -i zůstalo zachováno.
}

lově vyšší než koncovky - $u$ a -ou, 2. koncovka 1 sg - $u$ se ve spisovném jazyce šírí poměrně rychle, zatímco koncovka -ou jen pozvolna.

\section{Variantnost v 1sg a 3pl jako problém deskriptivní a kodifikační}

Existence variantních tvarů v 1 sg a 3 pl sloves vzorů kryje a kupuje se pochopitelně odráží i v mluvnických popisech češtiny, a to již od 17. století (blíže o tom viz Sojka 2017, s. 183-188). Pro vývoj moderní spisovné češtiny má samožrejmě největší význam stanovisko Dobrovského: ten ve své mluvnici zařazuje koncovku $1 \mathrm{sg}-u$ a koncovku 3pl -ou do obecné mluvy (gemeine Rede) a zároveň uvádí, že ve vytříbeném knižním jazyce používají Češi $\left(\right.$ Böhmen $\left.^{8}\right)$ s oblibou koncovky - $i$ a -i (viz Dobrovský 1809, s. 289). Autoři pozdějších mluvnic toto stanovisko vesměs respektují, ale například matiční Brusy (jejichž vliv byl nezanedbatelný především v oblasti školní jazykové výchovy) nezavrhují po měkkých souhláskách ani koncovky-u a -ou.

Počínaje devadesátými lety 19. století, tedy obdobím Gebauerovy kodifikace, se však př́stup ke koncovkám - $u$ a -ou, tedy $\mathrm{k}$ variantám kryju/kupuju a kryjou/kupujou, postupně zpř́ínnuje. V roce 1900 konstatuje Gebauer ve své nejpodrobnějš́ školské mluvnici, že koncovka $-u$ vniká namnoze i do jazyka spisovného, avšak u koncovky -ou se to týká pouze některých sloves vzoru tesati (viz Gebauer 1900, s. 156n.). V prvním vydání Pravidel českého pravopisu (dále jen PČP), obsahujícím úvodní Gebauerův mluvnický výklad, se však stanovisko zpř́isňuje i u koncovky - $u$ : ta podle PČP 1902 proniká do spisovného jazyka

\footnotetext{
${ }^{7}$ Výklad zde zužujeme na 3. prézentní třídu. Z historického hlediska je samožrejmě zajímavý i vývoj daného problému u sloves vzoru maže. Podle Havránka tu byla kodifikace koncovek $-i /-i$ v některých př́padech bezpředmětná: „Tvary oři, párí kář́, stůni zůstaly jen umělými př́klady gramatické kodifikace”" (Havránek 1936, s. 124). O dnešní situaci v tvarech 1 sg a 3 pl vybraných sloves vzoru maže viz Štícha et al. 2013, s. 465 .

${ }^{8}$ Regionální hledisko hrálo v mluvnických popisech důležitou roli. Např́ílad Rosa ve své mluvnici (1672) připisuje koncovku - $u$ po měkkých souhláskách Moravanům (viz Sojka 2017, s. 183).
} 
jen u některých sloves vzoru tesati. ${ }^{9}$ A konečně PČP 1941 toto stanovisko stvrzují zcela jednoznačným výrokem:

Máme jen: kryji, kryji, laji, laji, kupuji, kupuji. V těchto př́ípadech spisovný jazyk odchylek nedopouští (Pravidla... 1941, s. XLV).

Po druhé světové válce se pak začíná zvýšenou měrou diskutovat o tom, zda lze varianty 1 sg typu kryju/kupuju, př́padně i varianty $3 \mathrm{pl}$ typu kryjou/kupujou považovat za součást hovorové vrstvy spisovného jazyka. V př́spěvcích na toto téma lze identifikovat dva názory:

1. hovorový charakter má u vzorů kryje a kupuje pouze koncovka $1 \mathrm{sg}$ $-u$,

2. hovorový charakter má u obou vzorů jak koncovka 1 sg - $u$, tak i koncovka $3 \mathrm{pl}-$ ou.

První názor zastává např. Kopečný:

Z dvojice pracuju, pracujou je za hovorový možno pokládat jen tvar první, kdežto tvar kupujou je spíše lidový (obecně český) (Kopečný 1949, s. 19). ${ }^{10}$

Naproti tomu Jelínek je přesvědčen, že by budoucí kodifikační

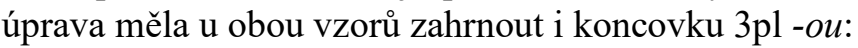

Nutnost sladit kodifikaci se stavem běžně mluveného jazyka si vyžaduje i úpravu v 1. sg. a 3. pl. sloves typů kryje, kupuje, a to dubletami kryji/kryju, kupuji/kupuju, kryjil/kryjou, kupujil/kupujou (Jelínek 1963, s. 53). ${ }^{11}$

Zajímavou variací na druhý názor (hovorovost koncovek - $u$ i -ou) je formulace z prvního i dalších vydání České mluvnice: podle autorů se pronikání obou koncovek do spisovného jazyka odehrává především u vzoru kryje, a to u sloves, která se „svým významem týkají

9 „Jinde však zachovává spisovný usus náležité $-i,-i ”$ (Pravidla... 1902, s. 57). Vzorů kryje a kupuje se toto konstatování týká bezvýhradně, což později potvrzuji i PČP 1941 (viz v textu).

${ }^{10}$ Podobně i Bělič 1958, s. 70 (posléze např. Brabcová 1987, s. 60),

${ }^{11}$ Podobně i Jedlička 1978, s. 106. Jedlička však zároveň - ve shodě s Gebauerovými výroky, citovanými zde v části 3 - upozorňuje na ,jemný rozdíl mezi tvarem singuláru a plurálu" (Jedlička 1978, s. 106). běžného života, jako zuju se, obujou, plejou, vyplejou apod" (Havránek, Jedlička 1951, s. 145). Autoři tedy naznačují, že koncovky -u a -ou se ve spisovném jazyce prosazují u různých sloves různou měrou: lze tu tedy hovořit o tzv. lexikální difuzi. Stejné hodnocení nalézáme později i v Mluvnici češtiny 2, avšak v rozšířené podobě:

Pouze slovesa knižní a na druhé straně slovesa s inherentním př́íznakem hovorovosti či expresivity, popř. slovesa vysloveně nespisovná mají jen tu z obou koncovek, která je v souladu s jejich celkovým slohovým zabarvením jako lexému (Komárek et al. 1986, s. 458).

K přijetí variant $1 \mathrm{sg}$ typu kryju/kupuju a variant $3 \mathrm{pl}$ typu $k r y j o u / k u$ pujou do kodifikace nakonec skutečně došlo, i když poněkud zvláštním způsobem: v případě sloves vzoru kryje se tak stalo již prvním vydáním Slovníku spisovné češtiny pro školu a veřejnost (dále jen SSČ) v roce 1978, v př́ípadě sloves vzoru kupuje explicitně až druhým vydáním SSČ (1994). ${ }^{12}$ Hodnocení této úpravy však nebylo a není jednoznačné. Zatímco kodifikace koncovky $-u$ byla přijata s pochopením, $v$ prípadě koncovky -ou se názory rozcházely ${ }^{13}$ a tento stav trvá dodnes. Např́klad Akademická gramatika spisovné češtiny (dále jen AGSČ), popisující jazyk publikovaných psaných textů, hodnotí koncovku 3 pl -ou u sloves 3. prézentní tř́ídy jako prostředek nespisovné obecné češtiny. ${ }^{14}$

${ }^{12}$ V PČP 1993 jsou koncovky - $u$ a -ou uvedeny pouze u sloves vzoru kryje, u sloves vzoru kupuje nikoli (podrobněji viz Sojka 2019, s. 269n.).

${ }^{13} \mathrm{~S}$ kodifikací koncovky -ou vyslovil nesouhlas Uličný: podle jeho názoru tato koncovka nesplňuje $\mathrm{v}$ př́ípadě sloves 3 . prézentní třídy požadavek stylové bezpříznakovosti a noremnosti (viz Uličný 1995, s. 66). Jelínek naopak kodifikaci koncovek -u i -ou přivítal, připustil však, že koncovka $3 \mathrm{pl}$-ou si zachovává silnější příznak hovorovosti než singulárová koncovka - $u$ (viz Jelínek 2004, s. 70).

${ }^{14}$ Viz Štícha et al. 2013, s. 452. Př́mo ve výkladech o 3. tř́iě slovesné se pak u obou vzorů uvádí, že zatímco koncovka $1 \mathrm{sg}-u$ se stále častěji prosazuje i v psaných textech, výskyt koncovky $3 \mathrm{pl}-o u$ je $\mathrm{v}$ psaných textech malý: $\mathrm{v}$ př́padě vzoru kryje „téměř zanedbatelný” (Štícha et al. 2013, s. 481), v př́ípadě vzoru kupuje „zanedbatelný" (Štícha et al. 2013, s. 484). 
Z výkladu v této části vyplývá, že pozice nověji kodifikovaných prézentních koncovek u sloves 3. třídy, tedy koncovky 1 sg $-u$ a koncovky $3 \mathrm{pl}-\mathrm{ou}$, není ve spisovné češtině stejná: zatímco koncovka $1 \mathrm{sg}$ $-u$ jeví silnější tendenci pronikat do spisovných textů (podle AGSC̆ i do spisovných textů psaných), koncovka 3 pl -ou nese zřetelnější příznak neformálnosti, a proto do spisovných textů proniká s menší intenzitou (do textů psaných podle AGSČ jen zanedbatelně).

\section{Popis výzkumného vzorku}

V empirické části př́spěvku hodláme popsat variantnost $\mathrm{v}$ tvarech 1 sg a 3pl sloves 3. prézentní tř́ídy v mluvených spisovných projevech, konkrétně na materiálu získaném analýzou publicistického pořadu Interview ČT24. ${ }^{15}$ Tento pořad je $\mathrm{k}$ danému účelu vhodný hned $\mathrm{z}$ několika důvodů:

1. většina hostů zde zřetelně usiluje o spisovnost,

2. hosty pořady jsou společensky významné osoby, většinou uvyklé veřejnému vystupování,

3. hosté v pořadu obvykle nevystupují jako soukromé osoby, nýbrž jako zástupci institucí,

4. soubor témat, o nichž se v pořadu diskutuje, podporuje užívání spisovného jazyka ${ }^{16}$,

5. pořad je vysílán živě, mluvený projev hostů je tedy spontánní, byt' na předem známé téma,

6. moderátoři pořadu, jsouce vázáni Kodexem ČT, zpravidla hovoří důsledně spisovně,

7. rozhovor většinou probíhá ve věcném tónu, téměř zde nedochází k emocionálně vypjatým momentům (ty by podporovaly nespisovnost).

15 Tento pořad se na veřejnoprávní stanici ČT24 vysílá od záŕí 2006, a to pravidelně každý všední den odpoledne.

${ }^{16}$ Jde o témata, která Uličný souhrnně nazývá tématy civilizačními: řadí k nim vědu, techniku, vzdělání, právo, informační prostředky, náboženství, členství v Evropské unii aj. (viz Uličný 2018, s. 337).
Pro analýzu jsme shromáždili dva dílčí vzorky: první pochází z období záŕí 2006 - květen 2007, druhý z období zář́i 2019 - květen 2020. ${ }^{17}$ Maximální možný časový odstup mezi dílčími vzorky (13 let) jsme zvolili proto, abychom mohli posoudit, zda se v tomto $-\mathrm{z}$ hlediska jazykového vývoje pravda krátkém odstupu - frekvence využití jednotlivých koncovek v rámci sledovaného pořadu změnila, či nikoli.

Dílčí vzorek z období 2006-2007 (dále jen V1) obsahuje 103 vysílání s celkem 239 výskyty tvaru 1 sg a 120 vysílání s celkem 439 výskyty tvaru $3 \mathrm{pl}$. Nestejný počet vysílání v dílčím vzorku je způsoben tím, že v některých vysíláních se vyskytly pouze tvary $3 p l$, ale nikoli tvary $1 \mathrm{sg}$ (výjimečně tomu bylo naopak). Dílčí vzorek z období 2019-2020 (dále jen V2) obsahuje 77 vysílání s celkem 192 výskyty tvaru 1 sg a 100 vysílání s celkem 475 výskyty tvaru $3 p{ }^{18} \mathrm{~V}$ obou dílčích vzorcích jsme uplatnili stejnou zásadu: každý host vystoupí pouze $\mathrm{v}$ jednom vysílání a ani mezi dílčími vzorky V1 a V2 se hosté nebudou opakovat (mladší vzorek V2 tedy obsahuje projevy jiných respondentů než starší vzorek V1).

Jako srovnávací zdroj jsme využili přepisy vybraných publicistických textů z korpusu DIALOG: 39 vysílání pořadu 7 čili Sedm dní (převážně texty z let 2003-2004) a 10 vysílání pořadu Otázky Václava Moravce (2004-2006). Tyto texty jsou žánrově poměrně blízké pořadu Interview ČT24 a pocházejí přibližně ze stejného období jako dílčí vzorek V1.

\section{Výsledky}

V analyzovaných vysíláních pořadu Interview ČT24 jsme v promluvách hostů zaznamenali všechny výskyty tvarů 1 sg a $3 p l$ sloves

${ }^{17}$ V̌̌echna vysílání jsou dostupná na https://www.ceskatelevize.cz/porady/1009 5426857-interview-ct24/dily.

${ }^{18}$ Sečteme-li oba dílčí vzorky, dospějeme $\mathrm{k}$ těmto hodnotám: 180 pořadů $\mathrm{s} 431$ výskyty tvaru $1 \mathrm{sg}, 220$ pořadů s 914 výskyty tvaru 3 pl. 
vzorů kryje a kupuje. Graf 1 podává informaci o tom, jak se v 1sg a 3pl těchto sloves realizovala konkurence stylově vy̌̌ších koncovek $-i /-i$ a stylově nižších, nověji kodifikovaných koncovek -u/-ou.

$1 \mathrm{sg}$

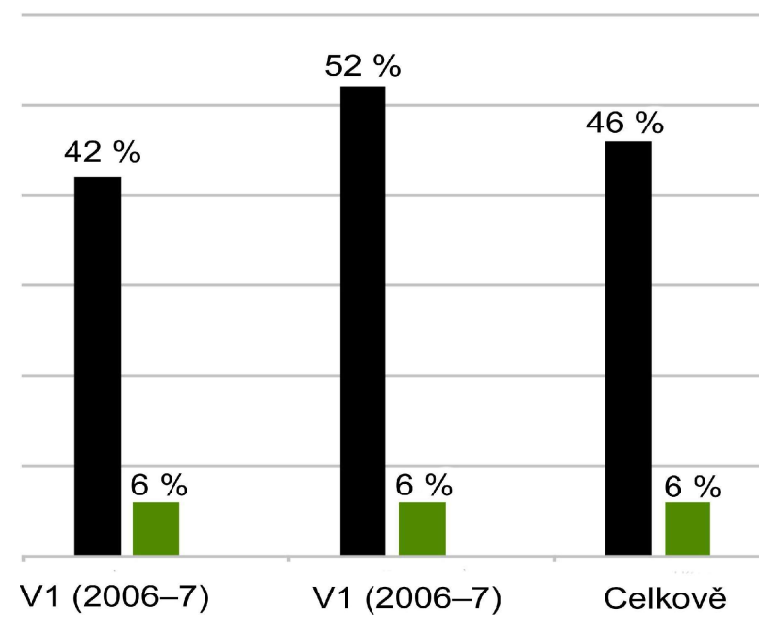

Graf 1. Koncovky $-u(1 \mathrm{sg})$ a -ou $(3 \mathrm{pl})$ v sondě Interview ČT24

$\mathrm{Z}$ grafu jednoznačně vyplývá, že $\mathrm{v}$ rámci dubletních párů $-i /-u$ $\mathrm{a}-i$-ou můžeme o skutečné konkurenci hovořit pouze $\mathrm{v}$ případě tvaru 1sg: výskyt koncovek $-i$ a $-u$ byl $\mathrm{v}$ obou dílčích vzorcích zcela rovnocenný, $\mathrm{i}$ když s mírným nárůstem podílu koncovky $-u \mathrm{v}$ mladším vzor$\mathrm{ku}$ V2. ${ }^{19}$ Ve tvaru 3pl měla naopak v obou dílčích vzorcích výraznou převahu koncovka $-i$.

Vyrovnaný podíl koncovek 1sg v obou dílčích vzorcích a její vyšší podíl v mladším vzorku nabízí možnost srovnat oba dílčí vzorky

${ }^{19}$ Vyšší podíl koncovky $1 \mathrm{sg}-u$ v mladším vzorku V2 však vzhledem k nevelkému rozsahu výzkumné sondy nelze přeceňovat. $\mathrm{Na}$ druhou stranu nelze vyloučit, že rozsáhlejší vzorek porovnávající data z obou časových období (2006-2007 a 2019-2020) by mohl tuto tendenci potvrdit. i z hlediska generační př́slušnosti respondentů. Vzhledem k časovému odstupu třinácti let, který oba vzorky dělí, je přirozené, že věkové složení je v obou př́padech jiné: ve vzorku V1 dominují osoby narozené v rozmezí 1950-1970, ve vzorku V2 jsou to osoby narozené v rozmezí 1960-1980. Dohromady obsahují vzorky 133 lexémů, prričemž 37 lexémů se vyskytuje v obou vzorcích (z hlediska výskytu tvarů představuje však těchto 37 lexémü ${ }^{20}$ celých $70 \%$ všech výskytů tvaru $1 \mathrm{sg}$ v obou vzorcích). Graf 2 obsahuje přehled výskytu koncovky $1 \mathrm{sg}-u \mathrm{v}$ obou dílčích vzorcích, a to podle dekády narození respondentů:

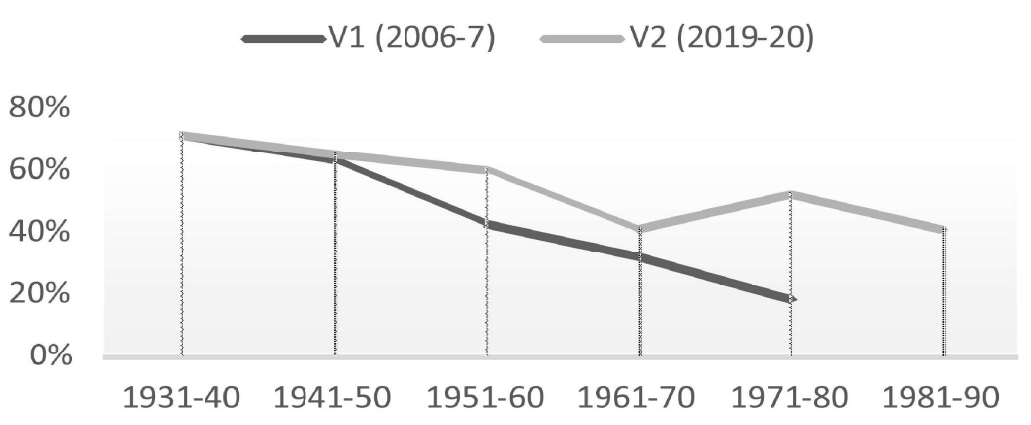

Graf 2. Koncovka -u (1sg) v sondě Interview ČT24 (podle dekády narození)

Údaje $\mathrm{v}$ grafu mohou působit poněkud překvapivě, nebot' ani $\mathrm{v}$ jednom $\mathrm{z}$ dílčích vzorků se u mladších respondentů podíl koncovky - $u$ nezvyšuje. Ve vzorku V2 (2019-2020) však pozorujeme od dekády 1951-1960 mírně vyšší a zároveň přece jen poněkud stabilnější výskyt koncovky $-u$. To by mohlo znamenat, že koncovka $-u$ je ve spisovných projevech tohoto typu perspektivní. V prípadě tvaru $3 p 1$ jsme

${ }^{20}$ Většinou jde o lexémy velmi frekventované: 27 z nich uvádí AGSČ jako nejfrekventovanější slovesa př́ślušných vzorů (viz Štícha et al. 2013, s. 480n. a 484). 
vzhledem k výrazné převaze koncovky -í od grafického znázornění upustili, generační faktor se tu však rovněž projevil: tendenci užívat koncovku 3pl -ou jevili spíše starší mluvčí, počínaje dekádou 1951-1960 je však převaha koncovky 3pl již velmi výrazná, a v dalších dekádách dokonce téměř absolutní (podíl konkurenční koncovky -ou nepřekračuje hranici tří procent).

Celkově lze říci, že výsledky v naší sondě odpovídají výše citovaným formulacím v AGSČ: zatímco nověji kodifikovaná koncovka 1 sg $-u$ představuje ve spisovných textech reálnou a zřejmě stále sílící alternativu $\mathrm{k}$ dříve kodifikované koncovce $-i^{21}$, ve 3 pl se nověji kodifikovaná koncovka -ou téměř neprosazuje. Tento výrazný rozdíl v pozici koncovek $-u$ a $-o u$ u sloves 3. prézentní třídy se $\mathrm{v}$ další části pokusíme vysvětlit.

Ještě dříve však srovnáme výsledky naší sondy s doklady získanými z korpusu DIALOG: v něm jsme tvarovou synonymii posuzovali v žánrově spř́zněných publicistických pořadech (7 čili Sedm dní, Otázky Václava Moravce). Výsledky představujeme v Grafu 3.

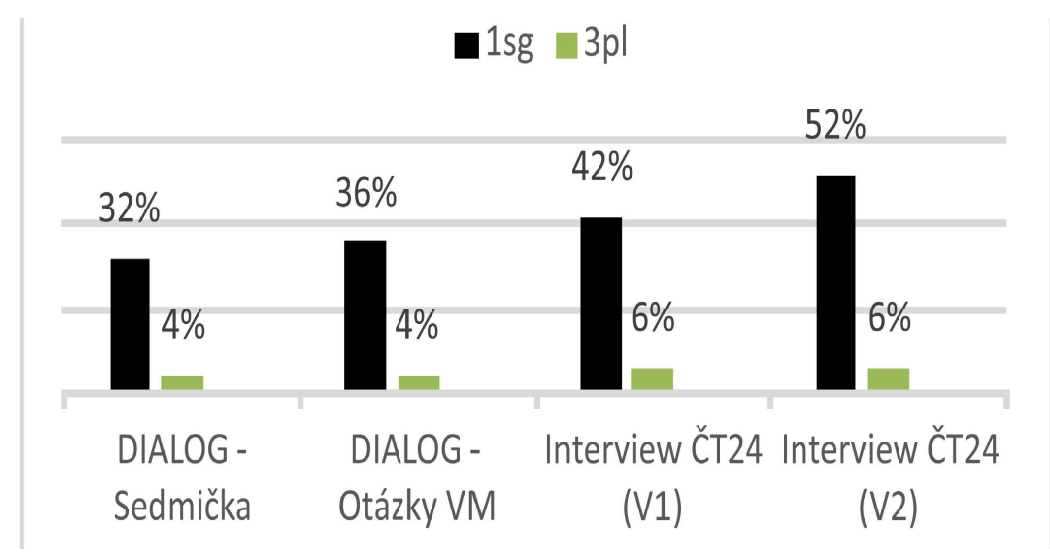

Graf 3. Koncovky $-u(1 \mathrm{sg})$ a -ou $(3 \mathrm{pl})$ v sondě Interview ČT24 a v korpusu DIALOG

${ }^{21}$ Ačkoli počet tvarů $1 \mathrm{sg}$ je $\mathrm{v}$ obou dílčích vzorcích relativně nízký, bližší pohled ukazuje, že koncovka $-u$ se neprosazuje u všech sloves stejnou měrou: např.
Data získaná z korpusu DIALOG se od výsledků naší sondy zásadně neodlišují: i v korpusu DIALOG se konkurence mezi dříve a nověji kodifikovanými koncovkami výrazně projevuje pouze v $1 \mathrm{sg}$, kdežto ve $3 p l$ výrazně převažuje koncovka -i (viz Čmejrková, Hoffmannová 2011, s. 201n.). Vyšší podíl koncovky 1sg -u v naší sondě (navíc s nárůstem jejího podílu mezi dílčími vzorky V1 a V2) by mohl svědčit o probíhající progresi této singulárové koncovky u sloves vzorů kryje a kupuje, avšak na základě dvou dílčích sond nelze takový závěr vyslovit $\mathrm{s}$ určitostí. V následující části se proto pokusíme vysvětlit toliko nejdůležitější fakt, jenž z naší sondy a ze srovnání s korpusem DIALOG vyplynul, tedy zcela odlišný projev tvarové konkurence ve tvaru $1 \mathrm{sg}$ a ve tvaru $3 \mathrm{pl}$.

\section{Interpretace výsledků}

Teze o rozdílné pozici singulárové koncovky $-u$ a plurálové koncovky -ou u sloves vzoru kryje a kupuje nemá oporu pouze ve výsledcích naší sondy, nýbrž i v mnohých starších i novějších bohemistických textech (mj. na tento jev upozorňoval již Gebauer). Protože výsledky naší sondy, zahrnující jeden konkrétní typ mluvených spisovných textů, v zásadě odpovídají situaci v publikovaných psaných textech (o nich hovoří AGSČ, viz výše), je namístě položit si otázku, proč se singulárová koncovka $-u$ prosazuje v některých žánrech spisovných textů dosti výrazně, zatímco koncovka -ou téměř vůbec ne. Nyní se tedy pokusíme pojmenovat faktory, které u sloves vzorů kryje a kupuje posilují pozici singulárové koncovky $-u$, a faktory, které u týchž sloves posilují pozici plurálové koncovky -i (čímž oslabují pozici koncovky -ou).

Pozici singulárové koncovky $-u$ posilují především následující faktory:

u slovesa pamatovat si měla koncovka $-u$ v obou vzorcích převahu (celkově $69 \%$ ), u slovesa považovat bylo zastoupení obou koncovek vyrovnané a u slovesa opakovat byl podíl koncovky - $u$ poněkud slabší, i když nezanedbatelný (33 \%). 
a) Koncovka $1 \mathrm{sg}$ - $u$ má oporu v jiných konjugačních typech: u sloves 1. třídy (s výjimkou některých sloves vzoru maže) a sloves 2 . třídy je koncovka $-u$ v 1 sg jedinou možnou variantou. Koncovka $-i$ tuto oporu nemá: s výjimkou nepravidelného slovesa chtít neexistuje žádné české sloveso, u něhož by v $1 \mathrm{sg}$ byla použitelná výlučně koncovka $-i{ }^{22}$ Progresi koncovky - $u$ můžeme proto u vzorů kryje a $k u$ puje považovat za projev meziparadigmatického vyrovnávání v prézentním časování sloves 1.-3. trrídy. Toto meziparadigmatické vyrovnávání míři $\mathrm{k}$ odstranění dublety $-u /-i$, a tedy výhledově ke snížení počtu koncovek ve tvaru 1 sg ze tří na dvě (v 1.-3. třídě $-u$, ve 4. a 5. tř́idě $-m$ ).

b) Koncovka $-u$ má u sloves 1.-3. třídy oporu v běžné mluvě, a to téměř na celém území (viz např. Bělič 1972, s. 188). Koncovka - $i$ je zde naopak zcela bez opory.

c) Koncovku - $u$ posiluje u sloves 3. třídy i faktor pragmatický. Z hlediska fonologické kombinatoriky je totiž ve spisovné češtině spojení ju expresivní. V první osobě singuláru je tato expresivnost přijatelná, nebot' první osoba označuje mluvčího, a je tedy inherentně expresivní (viz Uličný 2000, s. 214n.).

Pozici plurálové koncovky -i posilují následující faktory:

a) Koncovka 3 pl -i má oporu ve slovesech 4. a 5. tř́ídy, u nichž je ve spisovném jazyce tato koncovka jediná možná. To je skutečnost velmi závažná: zatímco totiž progrese singulárové varianty $-u$ vede výhledově ke snížení počtu koncovek v 1 sg ze tří na dvě $(-u,-m)$, $\mathrm{v}$ prŕípadě tvaru $3 \mathrm{pl} \mathrm{k}$ redukci počtu koncovek dojít nemůže. I kdyby totiž u sloves 3 . tř́dy převážila ve 3 pl koncovka -ou, nic by to nezměnilo na tom, že koncovka $3 \mathrm{pl}-i$ bude nadále existovat u sloves 4. a 5. tř́ídy. Jinak řečeno: koncovka $3 \mathrm{pl} \mathrm{-ou} \mathrm{nemůže} \mathrm{vyvinout}$ na koncovku - $i$ tak silný tlak, jaký vyvíjí koncovka 1 sg - $u$ na koncovku $-i$.

${ }^{22} \mathrm{~V}$ některých nespisovných útvarech lze koneckonců koncovku 1 sg $-u$ použít i u slovesa chtit. b) Distribuce koncovek ve tvaru $3 \mathrm{pl}$ je $\mathrm{v}$ běžně mluvené češtině složitější než v případě $1 \mathrm{sg}$. V běžně mluvené češtině „,východního" typu, zahrnující střední a východní Moravu a rovněž Slezsko, se totiž koncovka $3 \mathrm{pl}$-ou uplatňuje i u sloves 4. a 5. trídy (typy prosijou, délajou atd. ${ }^{23}$ ). Tyto varianty nesou zřetelný prríznak nespisovnosti, stejně jako „západní” varianty typu prosej, dělaj atd. Koncovka $3 \mathrm{pl}$ - $i$ je tedy u sloves 4 . a 5 . trí́dy jedinou spisovnou variantou, tedy variantou splňující požadavek celonárodní přijatelnosti. Z této skutečnosti si dovolujeme vyvodit následující závěr: vědomí nespisovnosti variant typu prosijou/dělajou může u mluvčích ,východní" češtiny posilovat ve spisovných projevech tendenci k užívání koncovky 3pl -í nejen u sloves 4. a 5. třídy, ale i sloves vzorů kryje a kupuje, a to kvůli analogickému hláskovému zakončení variant typu prosijou - dělajou - kryjou/kupujou (hláskové spojení jou je navíc expresivní, viz dále bod d).

c) Pozici variant typu kryjí/kupuji posiluje podle našeho názoru i shoda se slovesnými adjektivy typu kryjici/kupující (ve shodě s typem délající, sázejíci). ${ }^{24}$ Podoby typu *kryjoucí a *kupujoucí jsou sice teoreticky možné, avšak patrně zcela neuzuální. Tento argument může mít ale jen dočasnou platnost: např. u slovesa psát zní slovesné adjektivum píšicí (nikoli * píšouci), a přesto se tu koncovka $3 \mathrm{pl}$-ou používá dosti často.

d) Expresivní fonematické spojení jou je ve třetí osobě plurálu méně přijatelné než expresivní spojení ju v první osobě singuláru. Třetí osoba totiž neoznačuje mluvčího, a tudíž na rozdíl od osoby první není inherentně expresivní (viz Uličný 2000, s. 214n.). Navíc je

${ }^{23}$ Podle Bláhy je to jeden z progresivních (inovativních) rysů „východní” češtiny (viz Bláha 2009, s. 65), nebot' vede k unifikaci tvaru 3pl všech slovesných tř́íd. Bláhovu pojetí dáváme přednost před tradičním dialektologickým popisem, v němž se situace ve tvaru 3pl jeví jako ještě rozmanitěji (viz Bělič 1972, s. 189).

${ }^{24}$ Tradičně se za východisko těchto slovesných adjektiv považuje tvar přechodníku př́tomného pro singulár rodu ženského a středního (tedy kryjic > kryjicí). Protože však přechodník nepatř́ $\mathrm{k}$ běžně užívaným slovesným tvarům, lze vycházet i z tvaru 3pl (tedy kryji > kryjíci; viz Štícha et al. 2018, s. 836). 
třeba připomenout, že souhláskaj stojící před koncovkou 3pl spojuje vzory kryje a kupuje s početně velmi silným vzorem dělá (dělají, kryjí, kupují; shoda je tu i v imperativu: dělej, kryj, kupuj). ${ }^{25}$

\section{Závěr}

Konkurence kodifikovaných dubletních koncovek v 1 sg a $3 \mathrm{pl} \mathrm{u}$ sloves vzorů kryje a kupuje se v našem vzorku (vysílání pořadu Interview ČT24) neprojevovala jednotně. Zatímco v prípadě tvaru $1 \mathrm{sg}$ byl podíl koncovek $-i$ a $-u$ celkově zcela vyrovnaný, byt' s rozdíly $u$ jednotlivých sloves (projev lexikální difuze), $v$ prípadě tvaru $3 p l$ měla téměř absolutní převahu koncovka $-i$. $\mathrm{V}$ případě tvaru $1 \mathrm{sg}$ můžeme proto $\mathrm{v}$ našem vzorku hovořit o variantnosti (možná s mírnou progresí koncovky $-u)^{26}$, zatímco v případě tvaru $3 \mathrm{pl}$ o téměř naprosté unifikaci. Slovesa vzorů kryje a kupuje se tedy v našem vzorku projevovala jako s míš e né k o n j u g a č n í t y p y: progresivní koncovka 1sg-u je spojuje se slovesy 1. a 2. tř́́dy ${ }^{27}$, koncovka 3 pl - $i$ naopak se slovesy 4. a 5. tř́ídy. Odlišnou pozici nověji kodifikovaných koncovek (v 1sg $-u$, ve 3 pl -ou) lze vysvětlit závažnými systémovými faktory: pozici koncovky $1 \mathrm{sg}-u$ posiluje především skutečnost, že konkurenční koncovka - $i$ je $\mathrm{v}$ českém konjugačním systému nesamostatná (u pravidelných sloves to nikdy není jediná možná koncovka 1sg); pozici koncovky $3 \mathrm{pl} \mathrm{-ou} \mathrm{naopak} \mathrm{zásadně} \mathrm{oslabuje} \mathrm{skutečnost,} \mathrm{že} \mathrm{konkurenčni}$ koncovka $-i$ je jedinou spisovnou koncovkou ve 3 pl sloves 4 . a 5. tř́́dy.

${ }^{25}$ Viz již Kopečný 1949, s. 19. Kopečný upozorňuje i na shodu s tvary typu uměji (od r. 1993 je však ve 3pl kodifikována i varianta s nulovou kmenotvornou př́íponou, tedy umi).

${ }^{26}$ Máme tím na mysli skutečnost, že v dílčím vzorku V2 (tedy ve vzorku obsahujícím texty z let 2019-2020) byl podíl koncovky $1 \mathrm{sg}-u$ o $10 \%$ vyšší než ve starším vzorku V1 (texty z období 2006-2007) i než ve vybraných textech z korpusu DIALOG (texty z období 2003-2006).

${ }^{27}$ A rovněž tvar $1 \mathrm{pl}$, v němž vedle základní koncovky -me (typ kryjeme, kupujeme) existuje i stylově nižší koncovka -m (typ kryjem, kupujem). Tato tvarová synonymie je společná slovesům 1.-3. tř́ídy.
Za nesporný považujeme rovněž vliv faktoru pragmatického a uvažovat lze podle našeho názoru i o vlivu faktoru regionálního.

Výsledky naší sondy zároveň naznačují, že $\mathrm{v}$ jednom konkrétním žánru mluvených spisovných projevi̊ se distribuce koncovek $1 \mathrm{sg}$ a $3 \mathrm{pl}$ může velmi podobat situaci v publikovaných psaných spisovných textech (jak ji popisuje AGSČ) - v tom př́padě tedy distribuce koncovek neprobíhá na ose psanost - mluvenost, nýbrž je řízena výše popsanými faktory.

Shrnujeme tedy. $V$ př́ípadě tvaru $1 \mathrm{sg}$ můžeme v naší sondě hovořit o skutečné konkurenci mezi koncovkami $-u$ a $-i$, přičemž vývoj zde zřejmě pomalu míŕi k převaze koncovky $-u{ }^{28}$ Tuto skutečnost můžeme interpretovat jako meziparadigmatické vyrovnávání v rámci sloves 1.-3. slovesné třídy a zároveň jako součást obecnějšího procesu zjednodušování spisovného českého tvarosloví. ${ }^{29}$ Ve tvaru $3 \mathrm{pl} \mathrm{je} \mathrm{si-}$ tuace u vzorů kryje a kupuje zcela jiná: dominance koncovky -i otevírá prostor pro úvahu, zda koncovka -ou nebyla do kodifikace vnesena uměle, tedy v rozporu se spisovnou řečovou praxí.

\section{Literatura}

B ě 1 i č J., 1958, Vznik hovorové češtiny a její poměr k češtině spisovné. In: Havránek B., ed. Československé přednášky pro IV. mezinárodní sjezd slavistů v Moskvě. Vyd. 1. Praha: ČSAV, s. 59-71.

B ě 1 i č J., 1972, Nástin české dialektologie. Vyd. 1. Praha: SPN.

Bígl R., 2019, Vývoj lužickosrbského časování a slovotvorby. Vyd. 1. Praha: Karolinum.

B lá h a O., 2009, Funkční stratifikace češtiny. Vyd. 1. Olomouc: Univerzita Palackého, Filozofická fakulta.

\footnotetext{
${ }^{28}$ Nepředpokládáme však, že koncovka $1 \mathrm{sg}-i$ u sloves 3. prézentní třídy v příšstích několika desetiletích zcela ustoupí (tak jako zcela neustoupila ani u některých sloves vzoru maže). Domníváme se, že zvláště v projevech s vyšší mírou oficiálnosti bude její výskyt stále významný.

${ }^{29}$ Již v 50. letech konstatoval Dokulil, že česká tvaroslovná norma dospěje ke stabilitě teprve tehdy, až ,projde obdobím jistého, a to dosti hlubokého zjednodušení” (Dokulil 1952, s. 137).
} 
B ra b c ová R., 1987, Mluvený jazyk v teorii a praxi. Vyd. 1. Praha: Univerzita Karlova.

Č m e j r k ová S., H o ff m a n n o vá J., 2011, Mluvená čeština: hledání funkčního rozpétí. Vyd. 1. Praha: Academia.

De B ray R. G. A., 1969, Guide to the Slavonic languages. Vyd. 2., revidované. Londýn: J. M. Dent.

D o brov s ký J., 1809, Ausführliches Lehrgebäude der böhmischen Sprache, zur gründlichen Erlernung derselben für Deutsche, zur vollkommenern Kenntniß für Böhmen. Vyd. 1. Praha: Johann Herrl.

D o k u 1 il M., 1952, Kotázce normy spisovného jazyka a její kodifikace. (Přispěvek $k$ diskusi). „Slovo a slovesnost” 13, č. 3-4, s. 135-140.

G e b a u e r J., 1898, Historická mluvnice jazyka českého. Díl III, Tvarosloví. Část II. Casování. Praha a Vídeň: F. Tempský.

G e b a u e r J., 1900, Př́ruční mluvnice jazyka českého pro učitele a studium soukromé. Vyd. 1. Praha: Nákladem F. Tempského.

H a v rá n e k B. 1936, Vývoj spisovného jazyka českého. In: Československá vlastivěda. Řada II. Spisovný jazyk český a slovenský. Praha: Sfinx, s. 1-144.

H a v rá n e k B., J e d li č k a A., 1951, Česká mluvnice. Základní jazyková přiručka. Vyd. 1. Praha: Slovanské nakladatelství.

J e d l i č k a A., 1978, Spisovný jazyk v současné komunikaci. Vyd. 2., nezměněné. Praha: Univerzita Karlova.

Jelínek M., 1963, K poméru mezi hovorovou češtinou a spisovným jazykem. „Slovo a slovesnost” 24, č. 1, s. 47-54.

Jelíne k M., 2004, Osvědčily se úpravy českého spisovného časováni od roku 1957? „Universitas. Revue Masarykovy univerzity v Brně”, č. 3, s. 67-71.

K o már e k M. et al., 1986, Mluvnice češtiny 2. Vyd. 1. Praha: Academia.

K o p e č n ý Fr., 1949, Spisovný jazyk a jeho forma hovorová. „Naše řeč” 33, č. 1-2, s. 14-22.

Pravidla českého pravopisu s abecedním seznamem slov a tvarů, 1941, Praha: Školní nakladatelství pro Čechy a Moravu.

Pravidla hledící $k$ českému pravopisu a tvarosloví s abecedním seznamem slov a tvarů, 1902, Praha: Císařský královský školní knihosklad.

S o j k a P., 2017, Spisovné tvarosloví u dětí staršího školního věku. Praha: Vydavatelství Pedagogické fakulty Univerzity Karlovy.

S o j k a P., 2019, Tvaroslovná norma a kodifikační autorita. „Naše řeč” 102, č. 4, s. $265-276$.

Štích a Fr. et al., 2013, Akademická gramatika spisovné češtiny. Vyd. 1. Praha: Academia.

Š tí c h a Fr. et al., 2018, Velká akademická gramatika spisovné češtiny. I. Morfologie. Druhy slov. Tvořeni slov. Vyd. 1. Praha: Academia.
T o p o r i š i č J., 2000, Slovenska slovnica. Vyd. 4., přepracované a rozšǐřené. Maribor: Založba Obzorja.

U 1 i č ný O., 1995, Spisovná čeština a hodnotová orientace. In: J. Jančáková (ed.), Spisovná čeština a jazyková kultura 1993: sbornik z olomoucké konference 23.-27.8.1993. Praha: FF UK, s. 65-71.

U li čný O., 2000, O funkčnich aspektech některých morfologických prostředku českého národního jazyka. ,Stylistyka” IX. [Česká stylistika], s. 209-215.

U 1 i č n ý O., 2018, Lingvální a lingvistická situace češtiny k r. 2018. In: O. Bláha (ed.), Spisovná čeština a jazyková kultura 2018. Olomouc: Univerzita Palackého v Olomouci, s. 327-338.

V e č e r k a R., 2006, Staroslověnština v kontextu slovanských jazyků. Vyd. 1. Olomouc: Univerzita Palackého v Olomouci. 